\title{
Significance of Zinc Fertilizer on Nutrient Content and Uptake in Rice
}

\section{Muthukumararaja. $\mathrm{T}^{1}$ and M.V. Sriramachandrasekharan ${ }^{2}$}

${ }^{1}$ Assistent professor, Department of Soil Science and Agricultural Chemistry, Faculty of Agriculture, Annamalai University, Annamalai Nagar, India

${ }^{2}$ Professor, Department of Soil Science and Agricultural Chemistry, Faculty of Agriculture, Annamalai University, Annamalai Nagar, India

Abstract - A pot experiment was conducted during 2011 in a pot culture yard at Department of Soil Science and Agricultural Chemistry, Faculty of Agriculture, Annamalai University to studies on significance of zinc fertilizer on nutrient content and uptake in rice. The nutrient content and uptake of rice significantly improved on addition of graded dose of zinc in both Vertisol and Entisol. The result of experiment revealed that nutrient content and uptake ( $\mathrm{Zn}$ ) increased with zinc levels at all stages of crop growth. Nutrient content decreased while nutrient uptake

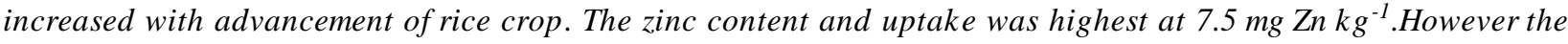
response of nutrient content and uptake in rice crop was higher in Entisol than Vertisol

Keywords-Content, uptake, zinc, rice.

\section{INTRODUCTION}

Stunted growth and small leaves are the most distinct $\mathrm{Zn}$ deficiency symptoms which are possibly due to changes in auxin metabolism, particularly of IAA (Alloway, 2003). Auxin synthesis in plants is also controlled by $\mathrm{Zn}$ (Skoog, 1940); hence, its deficiency leads to leaf distortion and a shortening of internodes (Irshad et al., 2004). Zinc role is as multifaceted, physiologically its role in a plant is either as a metal constituent in an enzymes or as a functional co-factor of number of enzyme reactions. In general, zinc deficient plant show signs of low levels of auxins such as indole acetic acid (IAA). Investigation gives sound footing that zinc is required for synthesis of tryptophan, which in turn is precursor for synthesis of IAA (Ali et al., 2012). Level of plant Zn content plays an important role on growth, nutrient composition and antioxidative enzymes activities of plants (Aydin et al., 2006). $\mathrm{Zn}$ is a structural part of carbonic anhydrase, alcohol dehydrogenase $\mathrm{Cu} / \mathrm{Zn}$ - superoxide dismutase and RNA polymerase and serves as a cofactor for all 6 classes of enzymes (oxidoreductases, transferases, hydrolases, lyases, isomerase and ligases) (Broadley et al., 2007). Application of $\mathrm{Zn}$ fertilizer in soil is a general strategy to cope up with Zn deficiency (Rengel et al., 1999) and to increase grain $\mathrm{Zn}$ concentration (Hussain et al., 2012).Realizing the importance of zinc efficient genotypes and biofertication to increase the zinc density in plant grain and at the same time seriousness of its deficiency in soils and plants, the present study was undertaken.

\section{MATERIALS AND METHODS}

With a view to study the significance of zinc fertilizer on nutrient content and uptake of rice in two soils was carried out during the year 2011 in a pot experiment in a net house of Department of Soil Science and Agricultural Chemistry, Faculty of Agriculture, Annamalai University. Bulk surface soil samples $(0-15 \mathrm{~cm})$ from two soil series (Kondal and Padugai) were collected air dried, powdered with wooden mallet. The experimental soil was clay loam and sandy clay loam in texture with $\mathrm{pH} 7.63 ; 7.30$, EC $0.70 ; 0.81 \mathrm{dS} \mathrm{m} \mathrm{m}^{-1}$, organic carbon $5.70 ; 8.20 \mathrm{~g} \mathrm{~kg}^{-1}$ (low), medium in $\mathrm{KMnO}_{4}-\mathrm{N} \quad 281 ; 284 \mathrm{~kg} \mathrm{ha}^{-1}$, high in Olsen-P 23.2;26.5 kg ha-1, high in $\mathrm{NH}_{4} \mathrm{OAc}-\mathrm{K} 306 ; 318 \mathrm{~kg} \mathrm{ha}^{-1}$ and low in available DTPA-Zn $0.75 ; 0.70 \mathrm{mg} \mathrm{kg}^{-1}$.The experiment was laid out in FCRD with three replication. The experiment consisted of two factors viz., Factor A Zinc levels (mg kg-1) $\mathrm{Zn}_{0}$ - Control (no zinc), $\mathrm{Zn}_{1}-2.5, \mathrm{Zn}_{2}-$ 5.0 and $\mathrm{Zn}_{3}-7.5$ and Factor $\mathrm{B}-$ Soil $\mathrm{S}_{1}-$ Kondal series (Typic Haplusterts) - Vertisol: $\mathrm{S}_{2}$ - Padugai series (Typic Ustifluvents) - Entisol. Before planting and application of fertilizers, the soil in all the pots were well puddled. All the pots were treated with basal dose of RDF (150:50:50 N, $\left.\mathrm{P}_{2} \mathrm{O}_{5}, \mathrm{~K}_{2} \mathrm{O} \mathrm{kg} \mathrm{ha}{ }^{-1}\right)$ in the form of urea, SSP and MOP and mixed with the soil. Zinc was applied as $\mathrm{ZnSO}_{4} .7 \mathrm{H}_{2} \mathrm{O}$ in the form of solution which was mixed thoroughly with soil. 
Three seedling of rice variety ADT 43 was planted pot $^{-1}$. The soils in the pots were kept at submergence throughout the crop period. At each stage,plant samples were collected from 24 pots $(8 \times 3)$ and calculate the uptake of nutrient in rice crop.

\section{RESULTS}

\section{Zinc content}

The data in Table 1 showed that various levels of zinc, soil type and their interaction significantly enhanced zinc content at all stages of crop growth over control. The zinc content ranged from 32.76 to $58.78 \mathrm{mg} \mathrm{kg}^{-1}$ (tillering stage), 26.93 to 52.53 (panicle initiation), 21.77 to $47.17 \mathrm{mg}$ $\mathrm{kg}^{-1}$ (grain) and 19.15 to $44.55 \mathrm{mg} \mathrm{kg}^{-1}$ (straw) due to application of various levels of zinc in two soils. The zinc levels increased with zinc doses and the highest zinc content was noticed with $7.5 \mathrm{mg} \mathrm{Zn} \mathrm{kg}^{-1}$. The zinc content decreased with stages of crop growth. At all stages of the crop growth, zinc content was higher in Entisol than Vertisol. However, the highest zinc content at all stages of crop growth was noticed when zinc was applied at $7.5 \mathrm{mg}$ $\mathrm{kg}^{-1}$ in Entisol.

\section{Zinc uptake}

Zinc uptake was significantly enhanced by addition of zinc, soils and their interaction over control (Table 2) at all stages of crop growth. Zinc uptake increased gradually with advancement of crop growth. Zinc uptake ranged from 379.7 to $766.0 \mu$ g pot $^{-1}$ (tillering stage), 550.4 to $2373.2 \mu \mathrm{g} \mathrm{pot}^{-1}$ (panicle initiation stage), 297.8 to $1997.2 \mu \mathrm{g} \mathrm{pot}^{-1}$ (grain) and 353.9 to $2647.2 \mu \mathrm{g} \mathrm{pot}^{-1}$ (straw). Zinc uptake increased steadily with zinc levels and the highest zinc uptake was noticed with $7.5 \mathrm{mg} \mathrm{Zn} \mathrm{kg}^{-1}$ at tillering stage $\left(738 \mu \mathrm{g} \mathrm{pot}^{-1}\right)$, panicle initiation stage (2065.2 $\mu \mathrm{g}$ pot $\left.^{-1}\right)$, grain $\left(1719.5 \mu \mathrm{g} \mathrm{pot}^{-1}\right)$ and straw $\left(2126.4 \mu \mathrm{g} \mathrm{pot}^{-}\right.$ $\left.{ }^{1}\right)$. The best treatment caused 83.4 per cent to 308.9 per cent increase in zinc uptake over control at different stages of crop growth. Irrespective of the stages of crop growth, zinc uptake was higher in Entisol than Vertisol.

\section{DISCUSSION}

\section{Nutrient concentration and uptake (zinc)}

Addition of graded dose of zinc improved zinc concentration and uptake in both soils. The zinc content was highest during tillering stage and progressively declined with advancement of crop growth probably due to dilution effect as a result of higher biomass production, while nutrient uptake increased with stages of crop due to increase in DMP. Graded dose of zinc increased zinc concentration and uptake and the highest value was noticed with $7.5 \mathrm{mg}$ $\mathrm{Zn} \mathrm{kg}^{-1}$ in both soils. Per cent increase in $\mathrm{Zn}$ uptake due to $7.5 \mathrm{mg} \mathrm{Zn} \mathrm{kg}{ }^{-1}$ over control was 83.4 to 68.5 per cent(Fig. 1). Zinc content of plant or uptake is controlled by many factors such as amount of soil DTPA-Zn, transfer of zinc to root surfaces and the interaction between $\mathrm{Zn}$ and other nutrients in the soil or within the plant (Robson, 1993). This was confirmed by the significant positive correlation between zinc uptake with available $\mathrm{N}(\mathrm{r}=0.98 * *$ (TS), $\mathrm{r}=0.98 * *(\mathrm{PI}), \mathrm{r}=0.99 * *$ (grain), $\mathrm{r}=0.98^{* *}$ (straw), available $\mathrm{P} \quad\left(\mathrm{r}=0.90^{* *}\right) \quad(\mathrm{TS}), \quad \mathrm{r}=0.86^{* *} \quad(\mathrm{PI}), \quad \mathrm{r}=0.93 * * \quad$ (grain), $\mathrm{r}=0.90 * *$ (straw) and available $\mathrm{K}(\mathrm{r}=0.98 * *(\mathrm{TS}), \mathrm{r}=0.99 * *$ (PI), $\mathrm{r}=0.97^{* *}$ (grain), $\mathrm{r}=0.95^{* *}$ (straw). Shehu and Jamala (2010) reported that application of $\mathrm{Zn}$ at 5.0, 7.5 and 10.0 $\mathrm{kg} \mathrm{ha}^{-1}$ had uptake advantage of 113,131 and 172 per cent over control.

Increase in zinc content and uptake in different parts of rice plant might be due to the presence of increased amount of DTPA-Zn in soil solution by the application of zinc that facilitated greater absorption (Fageria et al., 2011). The zinc content was higher in grain than in straw. Similar result was reported by Naik and Das (2008). Sharp increase in zinc uptake at greater $\mathrm{Zn}$ level might be related to greater increase in zinc concentration in soil solution at this zinc level. The above result was confirmed by significant positive correlation between DTPA-Zn with $\mathrm{Zn}$ uptake $\left(\mathrm{r}=0.95^{* *}\right.$ (TS), $r=0.96^{* *}$ (PI), $r=0.99 * *$ (grain), $r=0.96^{* *}$ (straw). Further, water soluble $\mathrm{Zn}$ had significant positive correlation in $\mathrm{Zn}$ uptake ( $\mathrm{r}=0.96^{* *}$ (grain), $\mathrm{r}=0.94 * *$ (straw). Similarly, exchangeable $\mathrm{Zn}$ had significant positive correlation with zinc uptake $\left(\mathrm{r}=0.87^{* *}\right.$ (grain), $\mathrm{r}=0.86^{* *}$ (straw). Wissuwa et al. (2008) and Veerendra Dixit et al. (2012) reported increase in $\mathrm{Zn}$ uptake on addition of $10 \mathrm{~kg} \mathrm{Zn} \mathrm{ha-1.}$

\section{CONCLUSION}

The present study find out zinc content and uptake

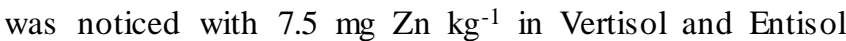
respectively. However the efficiency of rice was higher in Entisol than Vertisol.

\section{REFERENCES}

[1] Ali, R.I., T.H. Awan, M. Ahmed, M.U. Saleem and M. Akhtar. 2012. Diversification of rice-based cropping systems to improve soil fertility, sustainable productivity and economics. J. Animal and Plant Sci., 22: $108-112$. 
[2] Alloway, B.J. 2003. Zinc in soils and crop nutrition. International Zinc Association. http://zinc-crops.org. p. 114.

[3] Aydin, M., M.A. Demiral and M.A. Kaptan. 2006. Effect of zinc on growth, nutrient composition and antioxidative enzyme activity of maize as influenced by phosphorus. Int. J. Biol. Biotech., 3: 411-417.

[4] Broadley, M.R., P.J. White, J.P.Hammond, L. Zelko and A. Lux. 2007. Zinc in plants. New Phytol., 173: 677-702.

[5] Fageria, N.K., A.B. Das Santos and T. Cobucci. 2011. Zinc nutrition of lowland rice. Commun. Soil sci. Plant Ann. 42: 1719-1727.

[6] Hussain, S., M.A. Maqsood, Z. Rengel and T. Aziz. 2012. Biofortification and estimated human bioavailability of zinc in wheat grains as influenced by methods of zinc application. Plant. Soil, 36(1-2):279290.

[7] Irshad, M., M.A. Gill, T. Aziz, Rahmatullah and I. Ahmad. 2004. Growth response of cotton cutlivars to zinc deficiency stress in chelator-buffered nutrient solution. Pak. J. Bot., 36: 373-380.

[8] Naik, S.K. and D.K. Das. 2008. Relative performance of chelated zinc and zinc sulfate for lowland rice. Nutr. Cycling Agroecosyst., 81: 219-227.
[9] Rengel, Z., G. Battern and D. Crowley. 1999. Agronomic approaches for improving the micronutrient density in edible portion of field crops. J. Field Crops Res., 60: 28-40.

[10] Robson, A.D. 1993. Zinc uptake from soils. In: Zinc in soils and plants, Kluwer Academic Publishers, The Netherlands, pp.69-106.

[11] Shehu, H.E. and G.Y. Jamala. 2010. Available Zn distribution, response and uptake of rice (Oryza sativa L.) to applied $\mathrm{Zn}$ along a Toposequence of Lake Gerio Fadama soils at Yola, North Eastern Nigeria. J. Amer. Sci., 6(11): 1013-1016.

[12] Skoog, F. 1940. Relations between zinc and auxin in the growth of higher plants. Am. J. Bot., 27: 939-951.

[13] Veerendra Dixit, A.K.S. Parihar and Ganesh Shukla. 2012. Effect of sulfur and zinc on yield quality and nutrient uptake of hybrid rice in sodic soil. J. Agric. Sci. Tech., 1(2) 26-30.

[14] Wissuwa, M., A.M. Ismail and R.D. Graham. 2008. Rice grain zinc concentrations as affected by genotype, native soil zinc availability and zinc fertilization. Plant Soil, 306: 37-48. 


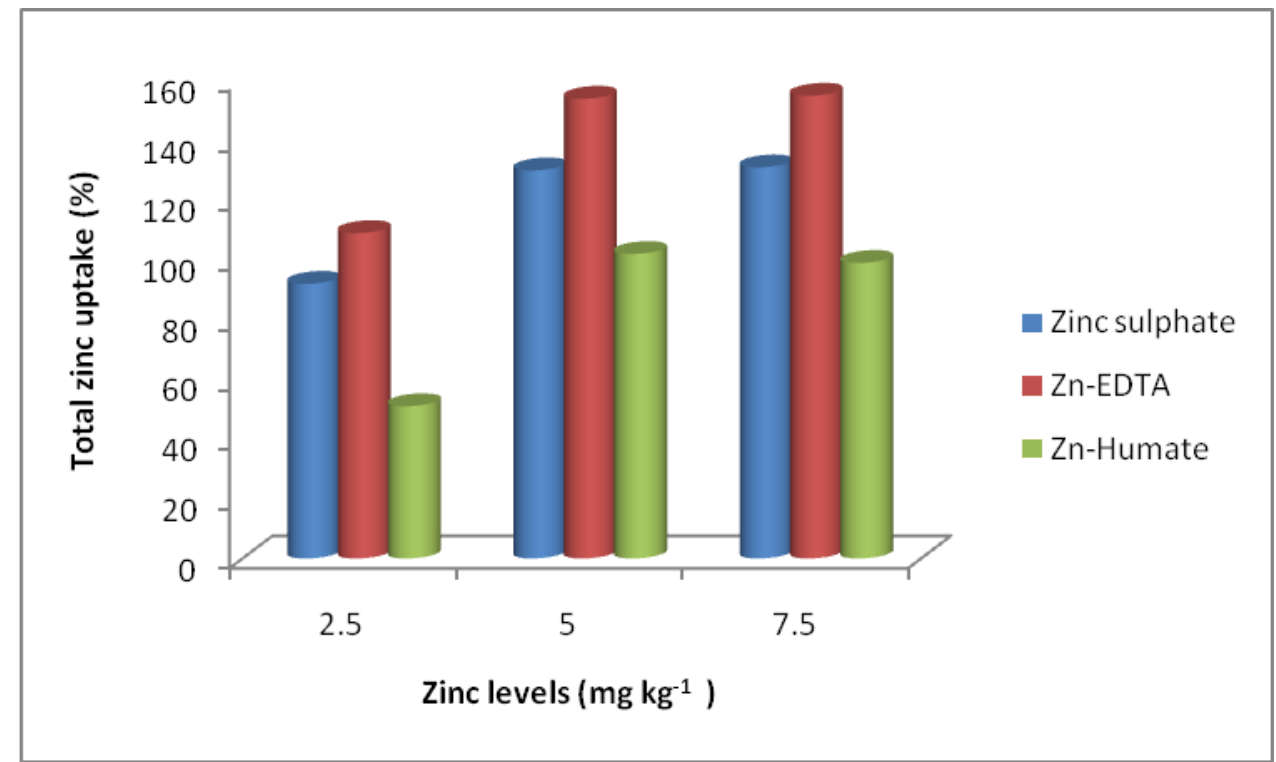

A

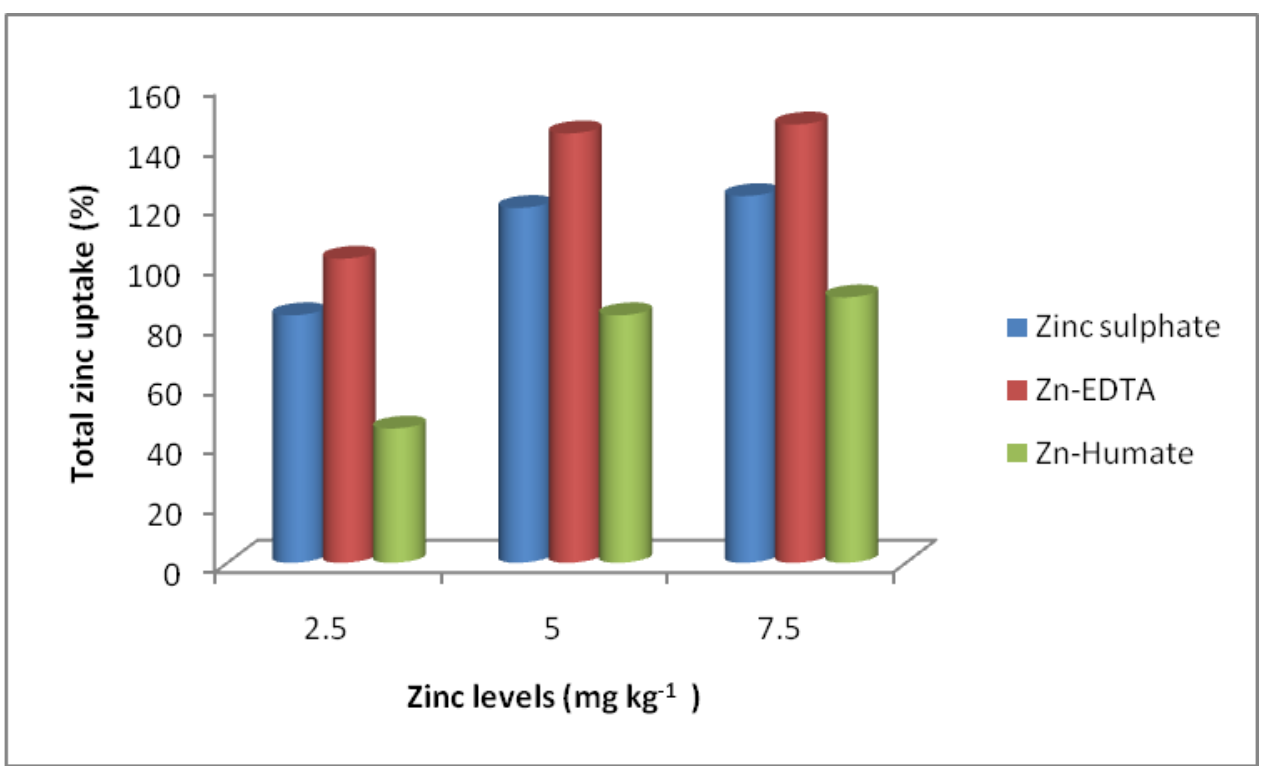

B

Fig. 1. Percentage increase in total Zn uptake
A) Vertisol
B) Entisol

Table 1. Effect of zinc application on zinc content $\left(\mathrm{mg} \mathrm{kg}^{-1}\right)$ at different stages of rice crop

\begin{tabular}{|c|c|c|c|c|c|c|c|c|c|c|c|c|}
\hline \multirow{2}{*}{$\begin{array}{c}\text { Zn levels } \\
\left(\mathrm{mg} \mathrm{kg}^{-1}\right)\end{array}$} & \multicolumn{2}{|c|}{ Tillering stage } & \multirow{2}{*}{ Mean } & \multicolumn{2}{|c|}{$\begin{array}{c}\text { Panicle initiation } \\
\text { stage }\end{array}$} & \multirow{2}{*}{ Mean } & \multicolumn{2}{|c|}{ Grain } & \multirow{2}{*}{ Mean } & \multicolumn{2}{|c|}{ Straw } & \multirow{2}{*}{ Mean } \\
\hline & $\mathbf{S}_{1}$ & $\mathbf{S}_{2}$ & & $\mathbf{S}_{1}$ & $\mathbf{S}_{2}$ & & $\mathbf{S}_{1}$ & $\mathbf{S}_{2}$ & & $\mathbf{S}_{1}$ & $\mathbf{S}_{2}$ & \\
\hline 0 & 32.76 & 33.92 & 33.34 & 26.93 & 28.12 & 27.52 & 21.77 & 22.96 & 22.36 & 19.15 & 20.34 & 19.74 \\
\hline 2.5 & 42.65 & 43.81 & 43.23 & 36.82 & 37.98 & 37.40 & 31.66 & 32.82 & 32.24 & 29.04 & 30.20 & 29.62 \\
\hline $\begin{array}{l}5.0 \\
\end{array}$ & 51.62 & 52.78 & 52.20 & 45.79 & 46.95 & 46.37 & 40.63 & 41.79 & 41.21 & 38.01 & 39.17 & 38.59 \\
\hline 7.5 & 57.00 & 58.16 & 57.58 & 51.14 & 52.33 & 51.73 & 45.98 & 47.17 & 46.57 & 43.36 & 44.55 & 43.95 \\
\hline
\end{tabular}




\begin{tabular}{|c|c|c|c|c|c|c|c|c|c|c|c|c|}
\hline Mean & 46.00 & 477.16 & & 40.17 & "41.34 & & 35.18 & 36.18 & & 32.39 & 33.56 & \\
\hline & $\mathrm{Zn}$ & $S$ & $\mathrm{Zn} \times \mathrm{S}$ & $\mathrm{Zn}$ & $S$ & $\mathrm{Zn} \times \mathrm{S}$ & $\mathrm{Zn}$ & $S$ & $\mathrm{Zn} \times \mathrm{S}$ & $\mathrm{Zn}$ & $S$ & $\mathrm{Zn} \times \mathrm{S}$ \\
\hline SEd & 0.53 & 0.37 & 0.75 & 0.85 & 0.60 & 1.20 & 0.57 & 0.40 & 0.80 & 0.83 & 0.58 & 1.17 \\
\hline $\begin{array}{c}C D \\
(p=0.05)\end{array}$ & 1.10 & 0.78 & 1.56 & 1.76 & 1.25 & 2.50 & 1.18 & 0.84 & 1.68 & 1.72 & 1.22 & 2.44 \\
\hline
\end{tabular}

Table 2. Effect of zinc application on zinc uptake $\left(\mu \mathrm{g} \mathrm{pot}^{-1}\right)$ at different stages of rice crop

\begin{tabular}{|c|c|c|c|c|c|c|c|c|c|c|c|c|}
\hline \multirow{2}{*}{$\begin{array}{l}\text { Zn levels } \\
\left(\mathrm{mg} \mathrm{kg}^{-1}\right)\end{array}$} & \multicolumn{2}{|c|}{$\begin{array}{l}\text { Tillering } \\
\text { stage }\end{array}$} & \multirow{2}{*}{ Mean } & \multicolumn{2}{|c|}{ Flowering stage } & \multirow{2}{*}{ Mean } & \multicolumn{2}{|c|}{ Grain } & \multirow{2}{*}{ Mean } & \multicolumn{2}{|c|}{ Straw } & \multirow{2}{*}{ Mean } \\
\hline & $\overline{S_{1}}$ & $\overline{S_{2}}$ & & $\overline{\mathbf{S}_{1}}$ & $\overline{\mathbf{S}_{2}}$ & & $\overline{S_{1}}$ & $\overline{\mathbf{S}_{2}}$ & & $\overline{S_{1}}$ & $\overline{\mathbf{S}_{2}}$ & \\
\hline 0 & 379.7 & 425.4 & 402.5 & 550.4 & 797.8 & 674.1 & 297.8 & 544.8 & 421.30 & 353.9 & 709.7 & 531.8 \\
\hline 2.5 & 523.7 & 579.6 & 551.6 & 1104.6 & 1470.6 & 1287.6 & 813.0 & 1203.2 & 1008.1 & 890.6 & 1602.4 & 1246.5 \\
\hline 5.0 & 645.8 & 710.4 & 678.1 & 1648.4 & 2153.6 & 1901.0 & 1301.8 & 1797.8 & 1549.8 & 1423.5 & 2344.0 & 1883.7 \\
\hline 7.5 & 709.6 & 766.0 & 738.0 & 1757.2 & 2373.2 & 2065.2 & 1441.9 & 1997.2 & 1719.5 & 1605.6 & 2647.2 & 2126.4 \\
\hline Mean & 565.0 & 620.3 & & 1265.1 & 1698.8 & & 963.6 & 1385.7 & & 1068.4 & 1825.8 & \\
\hline & $\mathrm{Zn}$ & $S$ & $\begin{array}{c}\mathrm{Zn} x \\
\mathrm{~S}\end{array}$ & $\mathrm{Zn}$ & $S$ & $\mathrm{Zn} \times \mathrm{S}$ & $\mathrm{Zn}$ & $S$ & $\mathrm{Zn} \times \mathrm{S}$ & $\mathrm{Zn}$ & $S$ & $\mathrm{Zn} \times \mathrm{S}$ \\
\hline SEd & 8.75 & 9.75 & 14.40 & 36.10 & 38.61 & 52.88 & 32.75 & 34.60 & 44.50 & 33.72 & 38.25 & 58.24 \\
\hline $\begin{array}{c}C D \\
(p=0.05)\end{array}$ & 18.20 & 20.30 & 30.00 & 75.10 & 80.32 & 110.00 & 68.13 & 72.10 & 92.50 & 70.14 & 79.56 & 121.15 \\
\hline
\end{tabular}

